\title{
The Effect of Some Environmental Factors on Growth Performance and Reproductive Traits in Saanen Goats
}

\author{
Deniz Dincel $^{1, \mathrm{a}}$, Sena Ardicli ${ }^{1, \mathrm{~b}}$, Hale Samli ${ }^{1, \mathrm{c}}$, M. Mustafa Ogan $^{2, \mathrm{~d}}$, Faruk Balci $^{1, \mathrm{e}, *}$ \\ ${ }^{1}$ Department of Genetics, Uludağ University, Faculty of Veterinary Medicine, TR-16059 Nilufer/Bursa, Turkey \\ ${ }^{2}$ Department of Zootechnics, Uludağ University, Faculty of Veterinary Medicine, TR-16059 Nilufer/Bursa, Turkey \\ *Corresponding author
}

\begin{tabular}{|c|c|}
\hline A R T I C L E I N F O & A B S T R A C T \\
\hline $\begin{array}{l}\text { Keywords: } \\
\text { Goats } \\
\text { Environmental factors } \\
\text { Reproduction } \\
\text { Growth } \\
\text { Saanen }\end{array}$ & $\begin{array}{l}\text { This study was carried out to determine the effect of non-genetic factors on growth and reproductive } \\
\text { traits in Saanen goats. For this aim, total of } 274 \text { Saanen goats and kids were investigated for growth } \\
\text { and reproductive traits in South Marmara Region of Turkey. Fertility parameters were evaluated } \\
\text { during two reproductive years. Saanen kids were measured from birth to } 6 \text { months of life. The } \\
\text { average live weights at birth, weaning, } 60^{\text {th }}, 90^{\text {th }}, 120^{\text {th }} \text { and } 180^{\text {th }} \text { days of age were calculated and } \\
\text { determined as } 3.05 \pm 0.04 \mathrm{~kg}, 11.80 \pm 0.27 \mathrm{~kg}, 12.26 \pm 0.08 \mathrm{~kg}, 14.20 \pm 0.32 \mathrm{~kg}, 17.41 \pm 0.45 \mathrm{~kg} \text {, } \\
25.01 \pm 0.65 \mathrm{~kg} \text {, respectively. The effects of sex and birth type on live weights until } 90^{\text {th }} \text { days of age; } \\
\text { maternal age only on birth weight; month at birth on all of investigated days were found significant } \\
\left.\text { statistically. The pregnancy, birth rate per pregnancy }\left(\mathrm{BR}^{\mathrm{P}}\right) \text {, birth rate per mating (BR }{ }^{\mathrm{M}}\right) \text {, infertility, } \\
\text { abortion, kidding rate (single, twin or triplet), survival rate (until weaning), number of kids per } \\
\text { parturition (NKP), number of kids per mating (NKM) were found; } 92.98 \%, 85.07 \%, 91.25 \%, 7.02 \% \text {, } \\
8.75 \%, 36.12 \% \text {, } 49.00 \% \text {, } 14.88 \%, 89.13 \% \text { and } 1.74 \pm 0.06 \text {, } 1.42 \pm 0.07 \text { respectively. The effects of } \\
\text { maternal age on all rates (out of BR }{ }^{\mathrm{M}} \text { and abortion rate); the year on birth, abortion, single kidding } \\
\text { rate, survival rate and NKM were found significant for reproductive traits. The advanced } \\
\text { reproductive performance and rapid growth rates were observed in Saanen goats. Environmental } \\
\text { factors such as age, year, sex, birth type and month at birth were found significant on some growth } \\
\text { and reproductive traits in Saanen. So consideration of these factors could be useful as a selection } \\
\text { criteria in dairy goat breeding. }\end{array}$ \\
\hline
\end{tabular}

deniz@uludag.edu.tr halesamli@gmail.com e fbalci@uludag.edu.tr
(iD) https://orcid.org/0000-0002-8015-9032
(i) https://orcid.org/0000-0003-4728-0735
(i) https://orcid.org/0000-0003-2382-1330

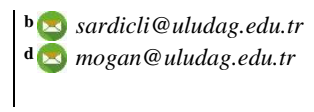

D https://orcid.org/0000-0003-2758-5945

D https://orcid.org/0000-0002-4046-3291

\section{Introduction}

Goats are valuable alternative livestock for breeders living in rural areas. According to Faostat (2016) average of one billion goats have been breeding for meat and milk productions in worldwide; mostly in developing countries located in Asia and Africa (Faostat, 2016). However, recently, the concern of goat breeding has also increased in developed countries such as Europe, South and North America (Selvaggi et al., 2014). Saanen dairy goats originate from Switzerland and they are known for their high milk production. These goats have a lactation period of 260-280 days and an average milk yield of 700-1000 kg (Yilmaz et al., 2016). Saanen goats are not only known as their advanced milk production in dairy goats but also their high adaptability and the tolerance of crushed feed (Ceyhan and Karadag., 2009). Superior production characteristics of Saanen ensure a high utilization in local breed improvement (Kulaksiz ve Daskin, 2012; Yilmaz et al., 2013).
Growth performance is another important criteria for animal breeding as it influences the time to reach the puberty (McManus et al., 2008). In addition, the birth and weaning weight are effective parameters for the survival of kids (Keskin et al., 2017).

The birth weight of Saanen kids was found 2.88-4.10 kg averagely (McManus et al., 2008; Ocak et al., 2006; Ceyhan and Karadag., 2009; Montaldo et al., 2010; Akoz et al., 2012;Teke at al., 2011; Akdag et al., 2011; Tolu and Savas, 2012; Ugur et al., 2004; Gokdal et al., 2017; Yilmaz et al., 2016). While the weaning weight was reported between 10.0 and $14.6 \mathrm{~kg}$ by McManus et al. (2008), Ceyhan and Karadag. (2009), Akdag et al. (2011), Tolu and Savas (2012), Ugur et al (2004), Yilmaz et al. (2016) and Gokdal et al. (2017); the $120^{\text {th }}$ day of live weight was determined $17.54-23.76 \mathrm{~kg}, 21.5 \mathrm{~kg}$ and $24.27-29.30 \mathrm{~kg}$ by Ocak et al. (2006), Ugur et al. (2004) and Gokdal et al. 
(2017) respectively. On the other hand, the $180^{\text {th }}$ day of live weight of Saanen kids was reported only by Gokdal et al. (2017) with 24.27-29.30 kg. McManus et al. (2008) indicated that the effect of month at birth was not found significant on birth and weaning weight while the effects of birth type and sex only on birth weight were found statistically significant. In contrast to McManus et al. (2008), Ocak et al. (2006) reported that the effect of birth type on live weights until $5^{\text {th }}$ months was found significant. Similar to Akdag et al. (2011), Teke at al. (2011) pointed out that the birth weight was not influenced by the birth type. However the effect of birth type on weaning weight was found significant by Teke et al. (2011). On the other hand, previous studies on the effects of sex, birth type, maternal age and month at birth on Saanen growth performance revealed often inconsistent results (Ocak et al., 2006; McManus et al., 2008; Akdag et al., 2011; Teke at al., 2011).

The strong adaptation capability and advanced fertility traits are very important traits in Saanen breeding (Jia and Wei, 2016; Akdag et al., 2011; Kyssa et al., 2014). The way to improve the yields within the flock is to increase the frequency of the female and male with high genotype structure (Tozlu Celik and Oflaz, 2015). The reproductive traits are directly proportionate to the litter size, and hence, they determine the size of the herd as well as profit rate of companies. The birth rate $\left(\mathrm{BR}^{\mathrm{P}}\right.$ or $\left.\mathrm{BR}^{\mathrm{M}}\right)$ of Saanen goats ranged from $80.95 \%$ to $100.00 \%$ in previous studies (Ceyhan and Karadag, 2009; Ulutas et al., 2010; Teke at al., 2011; Bolacali and Kucuk, 2012; Ince, 2010). However the knowledge about pregnancy rate of Saanen is limited in the literature; the reported pregnancy rates were $90.04 \%$ and $76.00-82.50 \%$ in studies performed by Bolacali and Kucuk (2012) and Sen and Onder (2016) respectively. The infertility and abortion rates were found $2.40-18.30 \%$ and 9.73-13.16\% in Saanen goats (Taskin et al., 2003; Ceyhan and Karadag., 2009; Ulutas et al., 2010; Teke at al., 2011; Bolacali and Kucuk., 2012; Ince, 2010; Akar, 2013). Multiple births are common in Saanen dairy goats (Jia and Wei, 2016; Kyssa et al., 2014). While the single kidding rate was determined 41.17-47.00\% (Ulutas et al., 2010; Teke et al., 2011; Bolacali and Kucuk, 2012; Kulaksız and Daskin, 2012; Sen and Onder, 2016; Ince, 2010); the twinning rate was found $41.00-71.73 \%$ by Ulutas et al. (2010), Teke at al. (2011), Bolacali and Kucuk. (2012), Kulaksiz ve Daskin (2012), Sen and Onder (2016) and Ince (2010). The triplet kidding rate was only reported by Sen and Onder (2016) and Kulaksiz et al. (2012) as 11.00$25.00 \%$ and $16.00 \%$ respectively. Survival rate is the most important trait influencing the income in goat breeding (Afzal et al., 2004; McManus et al., 2008). The survival rate of Saanen kids was defined as $89.60 \%$ to $98.43 \%$ in previous studies (Taskin et al., 2003; Ceyhan and Karadag., 2009; Ulutas et al., 2010; Teke at al., 2011). The NKP parameter was identified as 1.40 - 1.85 (Taskin et al., 2003; Ceyhan and Karadag., 2009; Ulutas et al., 2010; Teke at al., 2011; Bolacali and Kucuk., 2012; Mellado et al., 2008); the NKM was 1.20- 2.03 (Taskin et al., 2003; Ceyhan and Karadag., 2009; Ulutas et al., 2010; Teke at al., 2011; Bolacali and Kucuk., 2012; Sen at al., 2016) on an average. While the significant impact of age on all reproductive parameters was emphasized by Bolacali and Kucuk. (2012). In addition, these researchers reported the significant effects of year on abortion, single kidding, twining, NKP and NKM. On the other hand the effects of year and age on survival rate were just scrutinized by Taskin et al. (2003) and the significant effects on survival rate were reported by them. All about these traits investigated in previous studies located on a wide scale, hence the clarification of the values is significant.

In the literature, it can be clearly seen that growth and reproductive parameters show wide variations even if they are determined in the same environmental conditions. Moreover, to the best of our knowledge, the information about growth and reproductive traits (live weights after $90^{\text {th }}$ day of life-especially the weights of $120^{\text {th }}$ and $180^{\text {th }}$ day, triplet kidding rate or the effects of year and age on reproductive parameters) are limited. Therefore, the aim of this study was to determine the growth performance and reproductive traits of Saanen goats which raised in the South Marmara Region of Turkey. An additional aim of the present study was to evaluate the effect of some important factors such as age, year, birth type or month at birth on these traits.

\section{Material and Method}

\section{Animals}

The data were obtained from 274 Saanen goats and kids in South Marmara Region of Turkey; the latitude and longitude of the farm is $40^{\circ} 13^{\prime} 51.5^{\prime \prime} \mathrm{N} 28^{\circ} 52^{\prime} 31.0^{\prime \prime} \mathrm{E}$. The goats which randomly selected within the herd are genetically different from each other and reared intensively. The commercial concentrated feed (2500 $\mathrm{kcal} / \mathrm{kg}$ ) and dried clover were used ad libitum for the consumption of Saanen goats and kids. Saanen kids were sucking on average from birth to $60^{\text {th }}$ day of life. The haying crop and concentrated feed were given to kids 2-3 weeks after parturition and the fresh water were provided ad libitum. Total of 274 Saanen goats $(n=162)$ and kids $(n=112)$ were investigated for growth and reproductive performance. For all processing, ethical approval was received from Uludağ University (2012-04/03).

\section{Growth Performance}

The weights of Saanen kids $(n=112)$ were measured once a month from birth to average 6 months of life. The birth weight of the goats was recorded within 24 hours of birth (Ince,2010). The live weights at $60^{\text {th }}, 90^{\text {th }}, 120^{\text {th }}$ and $180^{\text {th }}$ days of age were calculated by the linear interpolation method (Powell, 1994). According to data; the effects of sex, birth type, maternal age and month at birth on average live weights at birth, weaning, $60^{\text {th }}, 90^{\text {th }}, 120^{\text {th }}$ and $180^{\text {th }}$ days of age were determined statistically.

\section{Reproductive Traits}

The natural mating was carried out at the autumn season (September-October) in Marmara Region, so that the does gave birth in February and March (kidding season). Parameters of reproductive traits were recorded during the two years of the study. The pregnancy, $\mathrm{BR}^{\mathrm{P}}$, $\mathrm{BR}^{\mathrm{M}}$, infertility, abortion, kidding rate (single, twin or triplet) rate, survival rate (until weaning), litter size as number of kids per parturition (NKP) and number of kids per mating (NKM) were calculated according to Kaymakci (2013). 


\section{Statistical Analyses}

General linear model procedure (GLM) was performed to determine the effects of sex, birth type, maternal age and month at birth on average live weight at the birth, weaning, $60^{\text {th }}, 90^{\text {th }}, 120^{\text {th }}$ and $180^{\text {th }}$ days of age by Minitab 15 statistical software programme (Minitab Inc., 2000) (Yalcin, 1975; Sumbuloglu and Sumbuloglu, 1994). For this purpose, a model (1) of was used to estimate growth performance of Saanen kids.

$$
\mathrm{Y}_{\mathrm{ijkl}}=\mu+\mathrm{C}_{\mathrm{i}}+\mathrm{D}_{\mathrm{j}}+\mathrm{E}_{\mathrm{k}}+\mathrm{F}_{\mathrm{l}}+\mathrm{e}_{\mathrm{ijklm}}
$$

\section{Where;}

$\mathrm{Y}=$ the dependent variable,

$\mu \quad=$ the overall mean,

$\mathrm{C}_{\mathrm{i}} \quad=$ the fixed effect of sex ( $\mathrm{i}=$ female or male),

$D_{j} \quad=$ the fixed effect of birth type $(j=$ single, twin, triplet $)$,

$\mathrm{E}_{\mathrm{k}}=$ the fixed effect of maternal age $(\mathrm{k}=1,2,3,4 \geq$ age $)$,

$\mathrm{F}_{1}=$ the fixed effect of month at birth (l= February, March)

$\mathrm{e}_{\mathrm{ijklm}}=$ the random error .

The following model (2) was used for the statistical analysis of weaning weights of Saanen kids;

$$
\mathrm{Y}_{\mathrm{ijklm}}=\mu+\beta \mathrm{G}_{\mathrm{i}}+\mathrm{C}_{\mathrm{j}}+\mathrm{D}_{\mathrm{k}}+\mathrm{E}_{\mathrm{l}}+\mathrm{F}_{\mathrm{m}}+\mathrm{e}_{\mathrm{ijklmn}}
$$

\section{Where;}

$\mathrm{Y}=$ the dependent variable,

$\mu \quad=$ the overall mean

$\beta=$ the constant of weaning age

$\mathrm{G}_{\mathrm{i}} \quad=$ the fixed effect of weaning age $(\mathrm{i}=58-71)$

$\mathrm{C}_{\mathrm{j}} \quad=$ the fixed effect of sex ( $\mathrm{i}=$ female or male)

$\mathrm{D}_{\mathrm{k}}=$ the fixed effect of birth type $(\mathrm{k}=$ single, twin, triplet $)$

$\mathrm{E}_{\mathrm{l}} \quad=$ the fixed effect of maternal age $(1=1,2,3,4 \geq$ age $)$

$\mathrm{F}_{\mathrm{m}}=$ the fixed effect of month at birth $(\mathrm{m}=$ February, March)

$\mathrm{e}_{\mathrm{ijklmn}}=$ the random error.

The effects of maternal age and year of birth on proportional reproductive performance were evaluated by chi square $\left(\chi^{2}\right)$ method (Yalcin, 1975). Fisher's exact chi square test was performed whether the observed value is less than 5 (Sumbuloglu and Sumbuloglu, 1994). On the other hand, the impacts of maternal age and the year of birth on litter size (Number of kids per parturition/mating) were analysed by One way ANOVA. InStat-Graph Pad Software (Graph Pad software V2.02+ 1990-1993, IS) were used in calculations.

\section{Results and Discussion}

\section{Growth Performance}

The average live weights of Saanen kids at birth, weaning, $60^{\text {th }}, 90^{\text {th }}, 120^{\text {th }}$ and $180^{\text {th }}$ days of age were given in Table 1, respectively. The birth weight $(3.05 \pm 0.04 \mathrm{~kg})$ of Saanen kids were in agreement with those reported by Ocak et al. (2006) and Akoz et al. (2012). This weight was not similar to data recorded by McManus et al. (2008), Ceyhan and Karadag. (2009), Teke et al. (2011), Akdag et al. (2011), Yilmaz et al. (2016) and Gokdal et al. (2017). It is known that the breeding conditions of goats influence the birth weight of the kids. The variation of birth weight may be derived from different management and breeding conditions as well as the genotype-phenotype interactions. Although the $60^{\text {th }}$ day of live weight of Saanen was lower than Ugur et al. (2004); it was found higher than Teke et al. (2011), Akdag et al. (2011) and Yilmaz et al. (2016). In addition, the weaning weight $(12.26 \pm 0.08 \mathrm{~kg})$ was consistent with Ceyhan and Karadag. (2009). Our results were lower than Ugur et al. (2004), Montaldo et al. (2010) and Akdag et al. (2011). This could be due to the different breeding performance of the goats or having different weaning age of kids. The weaning stress which affect the growth performance of kids might be another reason of various inspected weights.

The $90^{\text {th }}$ day of average live weight of Saanen goats was similar to results reported by Ocak et al. (2006) and Akdag et al (2011). However this finding was not consistent with Ugur et al. (2004) who indicated the $90^{\text {th }}$ day of average live weight was $17.5 \mathrm{~kg}$ in Saanen goats. Contrary to the results indicated by Akdag et al (2011), Ugur et al. (2004) and Gokdal et al. (2017); the $120^{\text {th }}$ day of average live weight $(17.41 \pm 0.45 \mathrm{~kg})$ was detected lower than the literature. Gokdal et al. (2017) pointed out that the $180^{\text {th }}$ day of live weight of Saanen goat was $24.27-29.30 \mathrm{~kg}$; this finding is similar to current study $(25.01 \pm 0.65 \mathrm{~kg})$ for the investigated day. The flock differences or climatic condition alterations were results of the different values of live weights. The breeding divergences could be another reason of variations.

Unlike the findings of Teke et al. (2011) and Akdag et al. (2011), McManus et al. (2008), Ceyhan and Karadag. (2009) and Ugur et al. (2004), current results showed that the effect of sex on average live weights at birth $(\mathrm{P}<0.001)$, weaning $(\mathrm{P}<0.001), 60^{\text {th }}$ day $(\mathrm{P}<0.001)$ and the $90^{\text {th }}$ days of age $(\mathrm{P}<0.05)$ were found to be statistically significant. Thus, the higher body weight was observed in male kids until $90^{\text {th }}$ day of life (Figure 1). These results were similar to Ocak et al. (2006) who emphasized the effects of sex and birth type on birth, $60^{\text {th }}$ day, $90^{\text {th }}$ day, and $120^{\text {th }}$ day of life were significant. This could be due to the massive body condition of the male than females depending on the physiological and hormonal structure. On the other hand, it was claimed by Afzal et al. (2004) that the sexuality of kids affected by the gestation period; the gestation period of the goats which pregnant to the male kids are longer than pregnant to the female male kids. In this respect, it was expected that the birth weight of male kids could be heavier than the others.

It was found that the birth type was found significant on average live weights at birth $(\mathrm{P}<0.001)$, weaning $(\mathrm{P}<0.01), 60^{\text {th }}(\mathrm{P}<0.01)$ and $90^{\text {th }}(\mathrm{P}<0.01)$ days of age. The effect of the birth type on birth weight was found in close agreement with McManus et al. (2008), Ceyhan and Karadag. (2009) and Ugur et al. (2004). Moreover the results showed that the birth type tended to be significant on $120^{\text {th }}$ day of live weight $(\mathrm{P}=0.053)$. This factor influenced the weights of Saanen goats in the study thus the single kids were determined heavier than the twin or triplet ones in this study. It is possible that the increasement in litter size may be caused a decrease in birth weight of kids. 
Table 1 Live weights $(\mathrm{kg})$ of Saanen kids in different periods.

\begin{tabular}{|c|c|c|c|c|c|c|c|c|c|c|}
\hline Factors & & $\mathrm{n}$ & $\mathrm{BW}$ & $\mathrm{P}$ & $\mathrm{n}$ & Day 60 & $\mathrm{P}$ & $\mathrm{n}$ & WW & $\mathrm{P}$ \\
\hline \multirow{2}{*}{ Sex } & $\mathrm{F}$ & 60 & $2.854 \pm 0.00^{b}$ & \multirow{2}{*}{$* * *$} & 57 & $10.81 \pm 0.32^{b}$ & \multirow{2}{*}{$* * *$} & 56 & $11.25 \pm 0.33^{b}$ & \multirow{2}{*}{$* * *$} \\
\hline & $\mathrm{M}$ & 52 & $3.249 \pm 0.05^{\mathrm{a}}$ & & 50 & $12.81 \pm 0.36^{\mathrm{a}}$ & & 49 & $13.27 \pm 0.37^{\mathrm{a}}$ & \\
\hline \multirow{3}{*}{ Birth Type } & 1 & 22 & $3.528 \pm 0.08^{\mathrm{a}}$ & \multirow{3}{*}{$* * *$} & 21 & $13.27 \pm 0.51^{\mathrm{a}}$ & & 21 & $13.76 \pm 0.54^{\mathrm{a}}$ & \multirow{3}{*}{$* *$} \\
\hline & 2 & 66 & $3.029 \pm 0.05^{\mathrm{b}}$ & & 63 & $11.69 \pm 0.34^{\mathrm{b}}$ & $* *$ & 61 & $12.16 \pm 0.35^{b}$ & \\
\hline & 3 & 24 & $2.596 \pm 0.09^{c}$ & & 23 & $10.46 \pm 0.60^{\mathrm{c}}$ & & 23 & $10.85 \pm 0.62^{\mathrm{c}}$ & \\
\hline \multirow{4}{*}{ Maternal age } & 1 & 26 & $2.734 \pm 0.07^{c}$ & \multirow{4}{*}{$* * *$} & 24 & $11.11 \pm 0.51$ & \multirow{4}{*}{ NS } & 24 & $11.49 \pm 0.52$ & \multirow{4}{*}{ NS } \\
\hline & 2 & 18 & $2.966 \pm 0.08^{b}$ & & 17 & $11.23 \pm 0.57$ & & 17 & $11.55 \pm 0.60$ & \\
\hline & 3 & 33 & $3.247 \pm 0.07^{\mathrm{a}}$ & & 32 & $12.03 \pm 0.47$ & & 30 & $12.66 \pm 0.49$ & \\
\hline & $4 \leq$ & 33 & $3.259 \pm 0.08^{\mathrm{a}}$ & & 32 & $12.87 \pm 0.56$ & & 32 & $13.34 \pm 0.61$ & \\
\hline \multirow{2}{*}{ Month at birth } & 2 & 85 & $3.154 \pm 0.05^{\mathrm{a}}$ & \multirow{2}{*}{$*$} & 82 & $13.05 \pm 0.32^{\mathrm{a}}$ & \multirow{2}{*}{$* * *$} & 80 & $13.58 \pm 0.33^{\mathrm{a}}$ & \multirow{2}{*}{$* * *$} \\
\hline & 3 & 27 & $2.948 \pm 0.07^{\mathrm{b}}$ & & 25 & $10.57 \pm 0.48^{b}$ & & 25 & $10.93 \pm 0.50^{b}$ & \\
\hline Mean & & 112 & $3.05 \pm 0.04$ & & 107 & $11.80 \pm 0.27$ & & 105 & $12.26 \pm 0.08$ & \\
\hline
\end{tabular}

\begin{tabular}{|c|c|c|c|c|c|c|c|c|c|c|}
\hline Factors & & $\mathrm{n}$ & Day 90 & $\mathrm{P}$ & $\mathrm{n}$ & Day 120 & $\mathrm{P}$ & $\mathrm{n}$ & Day 180 & $\mathrm{P}$ \\
\hline \multirow{2}{*}{ Sex } & $\mathrm{F}$ & 57 & $13.66 \pm 0.38^{b}$ & $*$ & 56 & $17.83 \pm 0.54$ & \multirow{2}{*}{ NS } & 50 & $25.00 \pm 0.73$ & \multirow{2}{*}{ NS } \\
\hline & $\mathrm{M}$ & 49 & $14.75 \pm 0.44^{\mathrm{a}}$ & $*$ & 46 & $17.00 \pm 0.62$ & & 36 & $25.02 \pm 0.93$ & \\
\hline \multirow{3}{*}{ Birth Type } & 1 & 20 & $15.87 \pm 0.62^{\mathrm{a}}$ & & 20 & $19.00 \pm 0.87$ & \multirow{3}{*}{ NS* } & 17 & $26.44 \pm 1.22$ & \multirow{3}{*}{ NS } \\
\hline & 2 & 63 & $14.03 \pm 0.41^{b}$ & $* *$ & 59 & $17.83 \pm 0.59$ & & 48 & $24.31 \pm 0.83$ & \\
\hline & 3 & 23 & $12.72 \pm 0.71^{\mathrm{c}}$ & & 23 & $15.42 \pm 1.01$ & & 21 & $24.28 \pm 1.39$ & \\
\hline \multirow{4}{*}{ Maternal age } & 1 & 23 & $13.69 \pm 0.61$ & \multirow{4}{*}{ NS } & 22 & $16.84 \pm 0.87$ & \multirow{4}{*}{ NS } & 16 & $24.21 \pm 1.25$ & \multirow{4}{*}{ NS } \\
\hline & 2 & 17 & $13.36 \pm 0.67$ & & 17 & $16.00 \pm 0.59$ & & 15 & $23.75 \pm 1.27$ & \\
\hline & 3 & 32 & $14.54 \pm 0.56$ & & 31 & $17.56 \pm 0.79$ & & 24 & $26.39 \pm 1.18$ & \\
\hline & $4 \leq$ & 32 & $15.20 \pm 0.67$ & & 30 & $19.26 \pm 0.98$ & & 29 & $25.69 \pm 1.28$ & \\
\hline \multirow{2}{*}{ Month at birth } & 2 & 82 & $15.72 \pm 0.38^{a}$ & \multirow{2}{*}{$* * *$} & 79 & $18.51 \pm 0.53^{\mathrm{a}}$ & \multirow{2}{*}{$*$} & 69 & $26.71 \pm 0.72^{\mathrm{a}}$ & \multirow{2}{*}{$*$} \\
\hline & 3 & 24 & $12.69 \pm 0.58^{b}$ & & 23 & $16.32 \pm 0.82^{b}$ & & 17 & $23.31 \pm 1.18^{b}$ & \\
\hline Mean & & 106 & $14.20 \pm 0.32$ & & 102 & $17.41 \pm 0.45$ & & 86 & $25.01 \pm 0.65$ & \\
\hline
\end{tabular}

$\mathrm{n}$ : number of the investigated animals, BW: birth weight, WW: Weaning weight, ***: $\mathrm{P}<0.001, * *: \mathrm{P}<0.01, *: \mathrm{P}<0.05, \mathrm{NS}:$ not significant, NS*:p=0.053, a,b,c. Different superscripts within a column indicate significant differences.
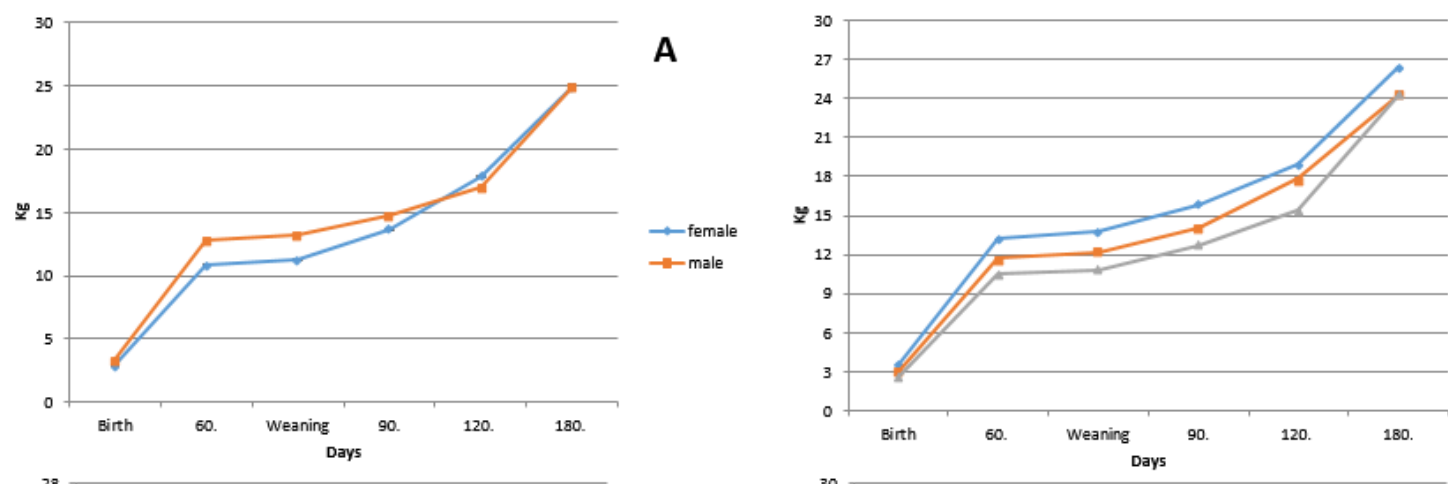

B
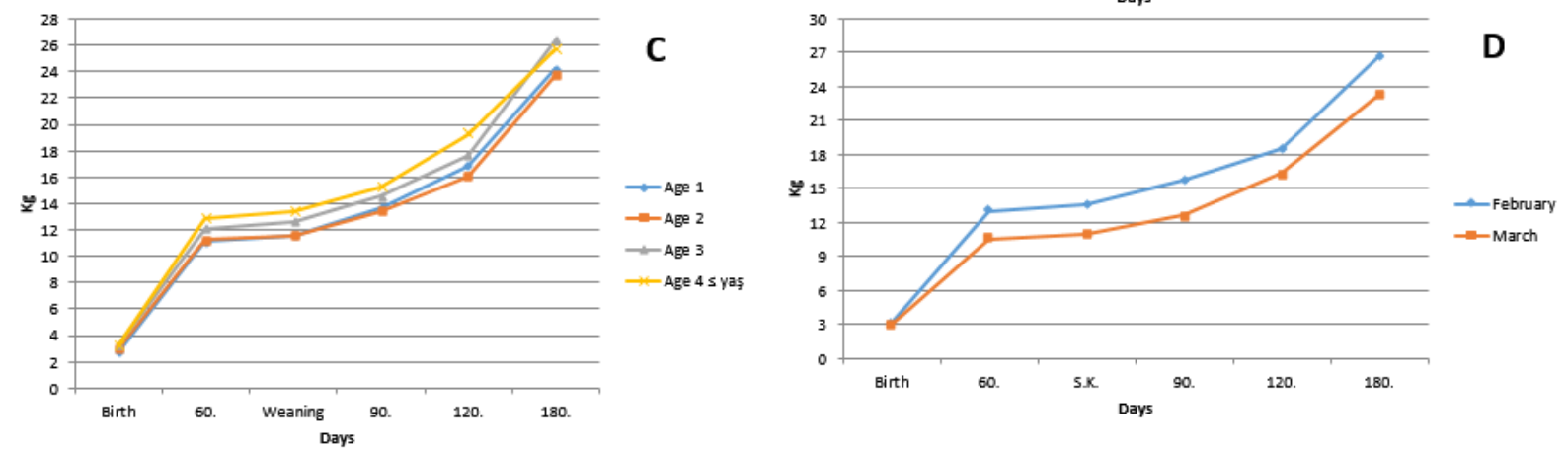

Figure 1 Growth performance of Saanen kids according to sex (A), birth type (B), maternal age (C) and month at birth (D) 
The maternal age was also only associated with the birth weight $(\mathrm{P}<0.001)$. This conclusion is consisted with data found in the literature by Ceyhan and Karadag. (2009). It is observed that the birth weight increases in proportion to the maternal age of the goats in there. This may be explained by the increase of the capability of uterine which is positively correlated with body development, in this case the development of uterine may provide the rise of kids enlargement capacity.

Also the effect of month at birth on all of investigated days [the birth, $120^{\text {th }}, 180^{\text {th }}$ days $(\mathrm{P}<0.05)$; the weaning, $60^{\text {th }}, 90^{\text {th }}$ days $(\mathrm{P}<0,001)$ were found to be significant, so the kid's born in March became more heavier than born in February until $180^{\text {th }}$ day of life in the study. It is thought that the dietary and conditional differences of goats during the pregnancy might affect the birth weights of the offspring. It was known that the year and season factors affect the milk composition in goats. For this reason, the goats giving a birth in February could have higher milk yield and composition than the ones giving a birth in March due to the alterations in bioclimatological factors. Therefore the exchanges of the quality and quantity of milk which were given to offspring might change the kids development.

\section{Reproductive Traits}

The pregnancy, $\mathrm{BR}^{\mathrm{P}}, \mathrm{BR}^{\mathrm{M}}$, infertility, abortion, single kidding rate, twinning, triplet kidding, survival rate, NKP and NKM were given in Table 2 and 3, respectively. A high pregnancy rate $(92.98 \%)$ was determined in the present study compared to the literature (Bolacali and Kucuk, 2012; Sen and Onder, 2016). The breeding and genotypic alterations might be a reason of differences between observed values (Sen and Onder, 2016). The $\mathrm{BR}^{\mathrm{P}}$ and the $\mathrm{BR}^{\mathrm{M}}$ were determined $85.07 \%$ and $91.25 \%$ in Saanen goats respectively. Although the advanced $\mathrm{BR}^{\mathrm{M}}$ was found in Saanen goats, compared to Ceyhan and Karadag. (2009), Ulutas et al. (2010) and Bolacali and Kucuk (2012); the lower rate of $\mathrm{BR}^{\mathrm{M}}$ was indicated by Teke at al. (2011). In addition the $\mathrm{BR}^{\mathrm{P}}$ was only reported by Ince (2010) and this rate $(100 \%)$ was observed lower than the present study.

The infertility rate of Saanen goats were defined to be
2.40-18.30\% in previous studies (Taskin et al., 2003; Ceyhan and Karadag., 2009; Ulutas et al., 2010; Teke at al., 2011; Bolacali and Kucuk., 2012; Ince, 2010). Our results showed that the infertility rate was lower than the studies performed by Ceyhan and Karadag. (2009), Bolacali and Kucuk (2012) and Ince (2010); but higher than Taskin et al. (2003), Ulutas et al. (2010) and Teke at al. (2011). It is that the heritability of fertility is low, and hence, the reproduction traits can be influenced from the environment. The observed variation could be derived from environmental factors such as breeding or care conditions.

In this study, the abortion rate was $8.75 \%$, which is relatively lower than the results reported by Ulutas et al. (2010), Bolacali and Kucuk (2012) and Akar (2013). The present results indicated that the single kidding rate was $36.12 \%$ in Saanen goats, which is lower than Ulutas et al. (2010), Teke at al. (2011), Bolacali and Kucuk (2012), Ince (2010), Sen and Onder (2016) and Akar (2013); but higher than Kulaksiz ve Daskin (2012). These differences might have aroused from the multiple births of investigated herd. The higher frequencies of twin or triplet births within the flock were observed, therefore a low single kidding rate was detected accordingly, in this study.

Contrary to the results published by Ulutas et al. (2010), Bolacali and Kucuk (2012), Taskin et al. (2003) and Teke at al. (2011), the twinning rate was determined (49\%) lower in the present study. It should be mentioned that the triplet births were accepted as twin births (multiple births) in the investigated herd by Ulutas et al. (2010), Bolacali and Kucuk. (2012), Taskin et al. (2003) and Teke at al. (2011), hence the twinnig rate was seem to be lower than the compared studies. Although our data were in close agreement with Kulaksiz ve Daskin (2012); it was found higher than Sen and Onder (2016) and Ince (2010) who indicated the twinning rates of $33-41 \%$ and $22.7-42.3 \%$ respectively. The Saanen goats investigated in current study, exhibited advanced multiple birth performances according to triplet births. The triplet kidding rate was determined 14.88 in Saanen goats in this study, this ratio is lower than Kulaksiz and Daskin (2012); but higher than Sen and Onder (2016).

Table 2 Reproductive parameters of Saanen goats according to year and age factors.

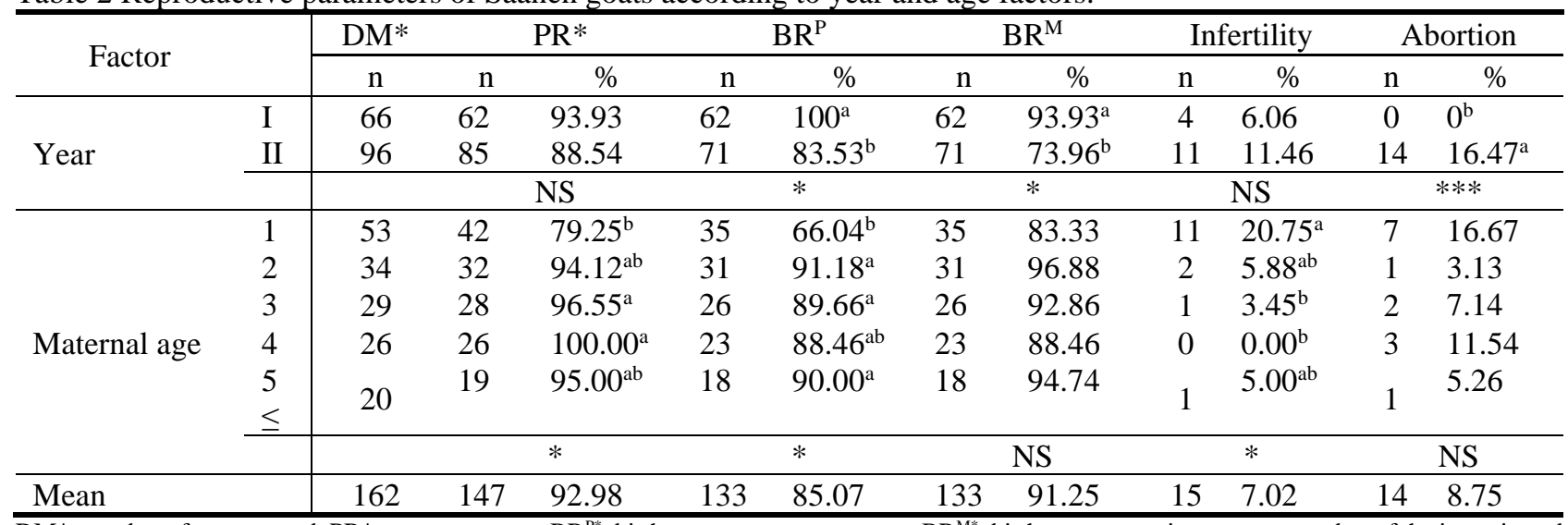

$\mathrm{DM}^{*}$ : number of goats mated, $\mathrm{PR}^{*}$ : pregnancy rate, $\mathrm{BR}^{\mathrm{P}^{*}}$ : birth rate per pregnancy rate, $\mathrm{BR}^{\mathrm{M}^{*}}$ : birth rate per mating rate, $\mathrm{n}=$ number of the investigated animals, $* * *=\mathrm{P}<0.001, * *=\mathrm{P}<0.01, *=\mathrm{P}<0.05, \mathrm{NS}=$ not significant, ${ }^{\mathrm{a}, \mathrm{b}, \mathrm{c}}=$ Different superscripts within a column indicate significant differences. 
Table 3 Reproductive parameters and survival rate of Saanen goats according to year and age factors (as a continuation of Table 2)

\begin{tabular}{|c|c|c|c|c|c|c|c|c|c|c|c|c|c|}
\hline \multirow{2}{*}{ Factor } & & \multicolumn{3}{|c|}{ Single* } & \multicolumn{2}{|c|}{ Twinning } & \multicolumn{2}{|c|}{ Triplet* } & \multicolumn{3}{|r|}{ SR } & \multirow[t]{2}{*}{ NKP* } & \multirow[t]{2}{*}{$\mathrm{NKM}^{*}$} \\
\hline & & Birth* & $\mathrm{n}$ & $\%$ & $\mathrm{n}$ & $\%$ & $\mathrm{n}$ & $\%$ & Kids* & $\mathrm{n}$ & $\%$ & & \\
\hline \multirow{3}{*}{ Year } & $\mathrm{I}$ & 62 & 20 & $32.25^{\mathrm{b}}$ & 33 & 53.26 & 9 & 14.51 & 113 & 108 & $95.58^{\mathrm{a}}$ & $1.82 \pm 0.08$ & $1.71 \pm 0.09^{\mathrm{a}}$ \\
\hline & II & 71 & 31 & $43.66^{\mathrm{a}}$ & 34 & 47.88 & 6 & 8.45 & 117 & 97 & $82.91^{\mathrm{b}}$ & $1.66 \pm 0.08$ & $1.23 \pm 0.09^{\mathrm{b}}$ \\
\hline & & & & $* *$ & & NS & & NS & & & $* *$ & NS & $* * *$ \\
\hline \multirow{5}{*}{$\begin{array}{l}\text { Maternal } \\
\text { Age }\end{array}$} & 1 & 35 & 24 & $68.57^{a}$ & 11 & $31.43^{\mathrm{c}}$ & 0 & $0.00^{\mathrm{b}}$ & 46 & 42 & $91.30^{\mathrm{ab}}$ & $1.31 \pm 0.47^{\mathrm{b}}$ & $0.86 \pm 0.10^{b}$ \\
\hline & 2 & 31 & 9 & $29.03^{b}$ & 22 & $70.97^{\mathrm{ab}}$ & 0 & $0.00^{\mathrm{b}}$ & 53 & 47 & $88.68^{a b}$ & $1.70 \pm 0.46^{\mathrm{ab}}$ & $1.56 \pm 0.11^{\mathrm{a}}$ \\
\hline & 3 & 26 & 5 & $19.23^{\mathrm{b}}$ & 20 & $76.92^{\mathrm{a}}$ & 1 & $3.85^{\mathrm{b}}$ & 48 & 46 & $95.83^{\mathrm{a}}$ & $1.85 \pm 0.46^{\mathrm{a}}$ & $1.66 \pm 1.13^{\mathrm{a}}$ \\
\hline & 4 & 23 & 7 & $30.43^{b}$ & 10 & $43.48^{\mathrm{bc}}$ & 6 & $26.09^{a}$ & 45 & 36 & $80.00^{\mathrm{b}}$ & $1.95 \pm 0.76^{\mathrm{a}}$ & $1.73 \pm 0.19^{\mathrm{a}}$ \\
\hline & $5 \leq$ & 18 & 6 & $\begin{array}{l}33.33^{\mathrm{b}} \\
* * *\end{array}$ & 4 & $\begin{array}{l}22.22^{\mathrm{c}} \\
*\end{array}$ & 8 & $\begin{array}{l}44.44^{\mathrm{a}} \\
\quad *\end{array}$ & 38 & 34 & $\begin{array}{l}89.47^{\mathrm{ab}} \\
*\end{array}$ & $\begin{array}{c}2.16 \pm 0.98^{\mathrm{a}} \\
* *\end{array}$ & $\begin{array}{c}1.95 \pm 0.26^{\mathrm{a}} \\
* *\end{array}$ \\
\hline Mean & & 133 & 51 & 36.12 & 67 & 49.00 & 15 & 14.88 & 230 & 205 & 89.13 & $1.74 \pm 0.06$ & $1.43 \pm 0.07$ \\
\hline
\end{tabular}

Birth*: number of total birth, Single*: single kidding rate, Triplet*: triplet kidding rate, Kids*: number of kids, SR*: survival rate of kids until weaning NKP*: number of kids per parturition, $\mathrm{NKM}^{*}$ : Number of kids per mating, $\mathrm{n}=$ number of the investigated animals, $* * *=\mathrm{P}<0.001, * *=\mathrm{P}<0.01, *=$ $\mathrm{P}<0.05, \mathrm{NS}=$ not significant, ${ }^{\mathrm{a}, \mathrm{b}, \mathrm{c}}=$ Different superscripts within a column indicate significant differences.

The survival rate $(89.13 \%)$, an important measurement for animal breeding, was similar to Ceyhan and Karadag. (2009), but lower than, 98.43\% (Taskin et al., 2003), $92.45 \%$ (Ulutas et al., 2010) and 95.2\% (Teke et al., 2011). Compared to Taskin et al. (2003), Ulutas et al. (2010) and Teke et al. (2011) the observed survival rate was lower. The observed decrement in survival rate might be explained by the differences of breeding programmes.

In present study, the NKP and NKM values were determined as $1.74 \pm 0.0$ and $1.42 \pm 0.07$. which are higher than the results reported by Ceyhan and Karadag. (2009), Ulutas et al. (2010), Teke at al. (2011), Mellado et al. (2008) and Bolacali and Kucuk. (2012). However our result for NKP was lower than Taskin et al. (2003) who indicated the same value as 1.85 . On the other hand the NKM was similar to data recorded by Taskin et al. (2003) and Sen and Onder (2016). The variations in genotypic and environmental properties, such as breed or management, might be a reason for the inconsistency in the literature.

There were no significant differences between the pregnancy, infertility, twinning, triplet rate or NKP according to years in investigated herd. However, the variations observed in birth rates $\left(\mathrm{BR}^{\mathrm{P}}, \mathrm{BR}^{\mathrm{M}}\right)(\mathrm{P}<0.05)$, abortion rate $(\mathrm{P}<0.001)$, single kidding rate $(\mathrm{P}<0.01)$, survival rate $(\mathrm{P}<0.01)$ and NKM $(\mathrm{P}<0.001)$ related to the year effect were found statistically significant. Consistent with the previous studies (Bolacali and Kucuk., 2012; Taskin et al., 2003) our results showed that the effect of year on infertility rate was significant, although there were no differences between the groups according to the age. According to year the birth rate was observed higher in first year than the second one. Also it was recognized that the survival rate and NKM had a higher value in the first year of the research. In opposite, the single kidding rate was observed higher in the second year of the study. Although the maternal age was found non-effective on $\mathrm{BR}^{\mathrm{M}}$ and abortion rate; it's effect on pregnancy rate $(\mathrm{P}<0.05), \mathrm{BR}^{\mathrm{P}}$ $(\mathrm{P}<0.05)$, infertility rate $(\mathrm{P}<0.05)$, single kidding rate $(\mathrm{P}<0.001)$, twinning rate $(\mathrm{P}<0.05)$, triplet kidding rate $(\mathrm{P}<0.05)$, survival rate $(\mathrm{P}<0.05)$, NKP $(\mathrm{P}<0.01)$ and $\mathrm{NKM}$ $(\mathrm{P}<0.01)$ was determined statistically significant. It was observed that the pregnancy and birth rates $\left(\mathrm{BR}^{\mathrm{P}}, \mathrm{BR}^{\mathrm{M}}\right)$ were increased with the age; the higher pregnancy rate was observed in three and four-year-old goats in present study. In addition multiple birth rates were increased with the age in Saanen goats. While the higher twinning rate was observed in three-year-old goats, triplet kidding was determined in goats older than 4 years. Moreover the current study in agreement with Bolacali and Kucuk. (2012) who reported the effects of year and maternal age on pregnancy, single kidding rate and NKM were significant. However the impact of year and age on pregnancy rate in the study conflicted with the results which was claimed by Bolacali and Kucuk (2012). On the other hand Taskin et al. (2003) emphasized that the survival rate until the weaning was not affected by the year and age factors. This aspect was also in disagreement with the current study. In addition the effects of year and age on NKM were similar to the study performed by Taskin et al. (2003). The reason for the above-mentioned differences with respect to impact of year and age factors on survival rate, single kidding rate or NKM in Saanen goats can be partially explained by environmental differences, such as raising conditions and management.

\section{Conclusion}

The results of the current study showed that the growth performance of Saanen kids was found better than the literature. In addition the reproductive performance of the same breed was observed higher than the comparative researches; in case of the reproductive parameters such as the multiple birth rate or NKM should be taken into consideration. Hence, it was concluded that this breed may be considerably appropriate for various goat breeding programmes. Furthermore, the effects of environmental factors such as age, year, month at birth, sex and birth type were significant on some growth and reproductive traits in Saanen goats. Consequently; consideration of the mentioned results may be useful in dairy goat breeding.

\section{Acknowledgements}

This research was supported by the funds from Uludağ University Scientific Research Projects Unit, Project Number OUAP(V)-2012/18.

\section{References}

Afzal M, Javed K, Shafiq M. 2004. Environmental effects on birth weight in Beetal goat kids. Pak Vet. J 24(2): 104-106. 
Akar Y. 2013. Reproductive performance of Saanen goats under rural or intensive management systems in Elazığ region, Turkey. Pak Vet. J 33(1): 45-47.

Akdag F, Pir H, Teke B. 2011. Comparison of growth traits in Saanen and Saanen X Hair crossbred (F1) kids. J. Anim. Prod 52(1): 33-38.

Akoz M, Zulkadir U, Karabacak A. 2012. The distrubition of births within a day in Saanen goats and the effect of some environmental factors on birth weight of kids and birth weight of goats. International Animal Science Congress of Turkish and Relatives Communities. Isparta-Turkey: pp 189-196.

Bolacali M, Kucuk M. 2012. Fertility and milk production characteristics of Saanen goats raised in Muş region. Journal of the Faculty of Veterinary Medicine, Kafkas University 18(3): 351-358.

Ceyhan A, Karadag O. 2009. Marmara Hayvancılık Araştırma Enstitüsünde Yetiştirilen Saanen Keçilerin Bazı Tanımlayıcı Özellikleri. J Agric Sci 15(2): 196-203.

Faostat: The number of the goats in 2016 according to the continental presence. http://www.fao.org/faostat/en/\#data/QA. Accessed: 31.05.2018.

Gokdal O, Ozugur AK, Atay O, Eren V. 2017. The effects of individual weaning based on birth weight on growth performance and milk yield in dairy goats. Turk J Vet Anim Sci 41: 672-678.

Ince D. 2010. Reproduction performance of Saanen goats raised under extensive conditions. Afr. J. Biotechnol. 9(48): 82538256.

Jia C, Wei Z. 2016. The complete mitochondrial genome of Xinong Saanen dairy goat (Capra hircus), Mitochondrial DNA Part A. doi: 10.3109/19401736.2015.1007302, 27:5, 3139-3140.

Kaymakci M. 2013. Measurements of fertility in goats. In: Ileri Keci Yetistiriciligi/Advanced goat breeding, $1^{\text {th }}$ ed., Meta Publishing Press, Izmir-Turkey: pp 47-53.

Keskin M, Gul S, Bicer O, Daskıran İ. 2017. Some reproductive, lactation, and kid growth characteristics of Kilis goats under semiintensive conditions. Turk J Vet Anim Sci 41: 248-254.

Kulaksiz R, Daskin A. 2012. Reproductive performance of primiparous and multiparous Saanen goats aft er laparoscopic intrauterine insemination: a field study. Turk J Vet Anim Sci 36(2): 201-204.

Kyssa I, Shulga A, Krylov D, Sergienia T. 2014. Relationships of goat breeding and farming with environmental protection and conservation. In: European Regional Conference on Goats, Romania: pp 67-70.

McManus C. Ilho GS, Louvandini H, Dias LT, Almeida Teixeira R, Murata LS. 2008. Growth of Saanen, Alpine and Toggenburg Goats in the Federal District, Brazil: Genetic and Environmental factors, Ciência Animal Brasileira, 9(1): 6875.

Mellado M, Mellado J, Valencia M, Pittroff W. 2008. The Relationship between Linear Type Traits and Fertility Traits in High-yielding Dairy Goats. Reprod Dom Anim 43: 599605 .
Montaldo HH, Torres-Hernandez G, Valencia-Posadas M. 2010. Goat breeding research in Mexico. Small Rum Res 89: 155163.

Ocak S, Guney O, Onder H, Darcan N. 2006. Growth and development performance of Cukurova Saanen kids under tropical climate conditions. J Anim Vet Adv 5(11): 985-989.

Powell MJD. 1994 A direct search optimization method that models the objective and constraint functions by linear interpolation, In: Advances in Optimization and Numerical Analysis, Kluwer Academic (Dordrecht): pp 51-67.

Selvaggi M, Laudadio V, Dario C, Tufarelli V. 2014. Major proteins in goat milk: an updated overview on genetic variability. Mol. Biol. Rep. 41(2): 1035-1048.

Sen U, Onder H. 2016. The effect of estrus synchronization programmes on parturition time and some reproductive characteristics of Saanen goats, J. Appl. Anim. Res., 44:1, 376-379.

Sumbuloglu K, Sumbuloglu V. 1994. Biyoistatistik/Biostatistics, $5^{\text {th }}$ ed, Ozdemir Press, Ankara-Turkey: pp 95-174.

Taskin T, Demiroren E, Kaymakci M. 2003. Saanen ve Bornova keçilerinde oğlak veriminin üretkenliği ve etkinliği. Ege Journal of Agricultural Research, 40(2): 33-40.

Teke B, Akdag F, Arslan S. 2011. Halk Elinde Yetiştirilen Saanen Keçilerinde Bazı Dölverimi, Büyüme ve Davranış Özellikleri. J. Fac. Vet. Med. Istanbul Univ 37(1): 1-8.

Tolu C, Savas T. 2012. Gökçeada, Malta ve Türk Saanen keçi genotiplerinin doğum ve oğlak büyümesi açısından karşıllaştırılması. J. Anim. Prod 53(2): 17-25.

Tozlu Celik H, Oflaz M. 2015. K1l keçi ve Saanen x Kıl keçi melezlerinin (F1, G1) üretici şartlarında döl verim özellikleri bakımından karşılaştırılması. Turkish JAF Sci.Tech 3(4): 164-170.

Ugur F, Savas T, Dosay M, Karabayır A, Atasoglu C. 2004. Technical Note:Growth and behavioral traits of Turkish Saanen kids weaned at 45 and 60 days. J Small Rum Res 52: 179-184.

Ulutas Z, Kuran M. Sirin E, Aksoy Y. 2010. Tokat şartlarında yetiştirilen Saanen ırkı keçilerin döl, süt verimi ve oğlakların gelişme özelliklerinin belirlenmesi. In: Proceeding of the National Goat Congress, Canakkale/Turkey: pp 215-218.

Yalcin BC. 1975. Bazı çevre faktörlerinin verim özellikleri üzerine etkilerinin istatiksel eleminasyonu. J. Fac. Vet. Med. Istanbul Univ 1(1): 82-102.

Yilmaz M, Bardakcioglu HE, Altin T. 2016. Comparison of Some Body Measurements for Saanen goats. Scientific PapersAnimal Science Series: Lucrări Ştiinţifice - Seria Zootehnie, 65: 134-137.

Yilmaz O, Kucuk M, Bolacalı M, Cak B. 2013. Investigation of survival rate, growth performance and some body measurements of Saanen x hair goat F1 crossbred and pure hair goat kids raised in semi-intensive conditions. Bulg $\mathrm{J}$ Agric Sc1 19(4): 835-840. 